\title{
Uroporphyrin- and Coproporphyrin I-accumulating Mutant of Escherichia coli $\mathrm{K} 12$
}

\author{
By P. CHARTRAND,* D. TARDIF AND A. S ĂS ĂRMN† \\ Department of Microbiology and Immunology, University of Montreal, \\ Montreal, Quebec, Canada
}

(Received 4 July 1978)

\begin{abstract}
A new type of haem-deficient mutant was isolated in Escherichia coli $\mathrm{K} 12$ by neomycin selection. The mutant was deficient in uroporphyrinogen III cosynthase activity as indicated by the accumulation of uroporphyrin I and coproporphyrin I. The mapping of the corresponding hemD gene by Pl-mediated transduction showed that the new gene was located between ilv and cya, at min 83 on the chromosomal map of Escherichia coli $\mathrm{K} 12$.
\end{abstract}

\section{INTRODUCTION}

Congenital erythropoietic porphyria in man is an autosomal recessive disease which is due to a partial deficiency in uroporphyrinogen (UROGEN) III cosynthase activity (Bogorad, 1958; Levin, 1975; Fig. 1). Its clinical manifestations are the result of the formation of large amounts of uroporphyrin (URO) I and coproporphyrin (COPRO) I (Levin, 1975 ) but the exact mechanism of the disease is difficult to analyse in man. Bacteria represent an ideal model for the study of this deficiency, because the steps in porphyrin synthesis are the same in bacteria and in higher organisms. The corresponding bacterial mutants could also be helpful for the understanding of the mechanism of conversion of porphobilinogen (PBG) to UROGEN III. This step is thought to involve the interaction of UROGEN I synthase and UROGEN III cosynthase and the mechanism of this interaction is highly controversial (Lascelles, 1964; Tait, 1968; Frydman et al., 1975; Higuchi \& Bogorad, 1975; Shemin, 1975).

The screening of a large number of haem-deficient mutants of Escherichia coli $\mathrm{K} 12$ led to the identification of a new type of mutant which accumulated URO I and COPRO I. Such an accumulation would be expected for a mutant deficient in UROGEN III cosynthase activity (Fig. 1) and was confirmed by further biochemical studies. The results of these studies on the mutant and of the genetic mapping of the corresponding hemD gene are described in the present report.

\section{METHODS}

Bacterial strains. The derivatives of $E$. coli $\mathrm{k} 12$ used for biochemical and genetic studies are listed in Table 1.

Media. The basic medium for growing the bacterial strains was brain heart infusion (BHI; Difco) supplemented, when necessary, with 1.5 to $2 \%(\mathrm{w} / \mathrm{v}$ ) Bacto-agar (Difco). Simmons agar base (Difco), supplemented with $0.4 \%(\mathrm{w} / \mathrm{v})$ glucose and the required growth factors, was the synthetic medium used for genetic analysis.

Chemicals. Organic solvents for the extraction and identification of porphyrins were reagent or USP grade. Peroxides were removed from diethyl ether as described by Perrin et al. (1966). Haemin, porphyrin methyl esters and porphyrin precursors were obtained from Sigma and were Sigma grade, except for uroporphyrin I octamethyl ester ( $85 \%$ pure). Several samples of pure porphyrin esters were the generous gift of S. F.

* Present address: Institute of Virology, University of Glasgow, Glasgow G11 5JR.

$\dagger$ To whom reprint requests should be sent. 


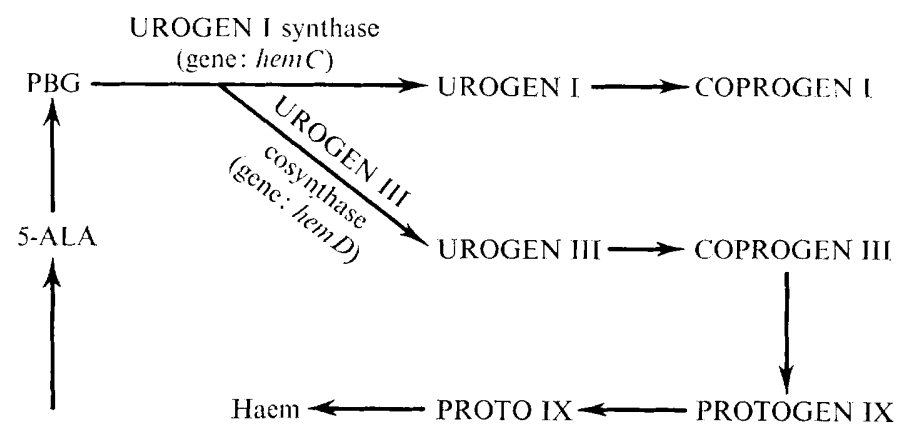

Fig. 1. Simplified scheme of the biosynthesis of haem (Bogorad, 1958; Lascelles, 1964; Tait, 1968; Shemin, 1975). Abbreviations: 5-ALA, 5-aminolaevulinic acid; PBG, porphobilinogen; UROGEN, uroporphyrinogen; COPROGEN, coproporphyrinogen; PROTOGEN, protoporphyrinogen; PROTO, protoporphyrin.

Table 1. Derivatives of E. coli $\mathrm{K} 12$ used

\begin{tabular}{|c|c|c|c|}
\hline Strain & Genotype* & Origin & Source \\
\hline ASz31 & hemD 31 mutation in SAs 245 & Neomycin selection & This laboratory \\
\hline As 245 & metE46, chlB2, his-1, argH1, thi-1, xyl-7, str-I21 & & This laboratory \\
\hline $\begin{array}{l}\text { tir Cavalli } \\
\text { As } 343\end{array}$ & $\begin{array}{l}\text { metB } 1, \text { rel- } 1 \text {, } \\
\text { cya- } 2, \text { thr }-1 \text {, leu- } 6, \text { pro-36, trp-42, ilvD } 75, \text { lac } Y 1 \text {, } \\
\text { gal-6, mtl-2, str-9; F- }\end{array}$ & P1 LS $853 \times$ SAS 229 & $\begin{array}{l}\text { W. Hayes } \\
\text { This laboratory }\end{array}$ \\
\hline As 229 & $\begin{array}{l}\text { thr-1, leu-6, pro-36, trp-42, ilvD75, metE46, lacYl, } \\
\text { gal-6, mtl-2, str-9; F- }\end{array}$ & $\dagger$ & This laboratory \\
\hline s853 & cya- $2, \operatorname{trp} R 55, \operatorname{trp} A 9605$, his- $85,(\lambda)^{-}, \mathrm{F}^{-}$ & L. Sol strain & $\begin{array}{l}\text { B. Bachmann } \\
\text { (CGSC } \\
\text { no. } 5381)\end{array}$ \\
\hline A6021 & $\begin{array}{l}\text { thr-1, leu-6, thi-1, } \arg H 1, \text { purE } 43, \text { pro-36, trp- } 42, \\
\text { lac } Y 1, \text { xyl-7, mtl-2, ara-13(?), malAl, gal-6, } \\
\text { tonA2(?), } \lambda^{r}, \text { str-9, rel-l(?) }(\lambda)^{-} ; \mathrm{F}^{-}\end{array}$ & & F. Jacob \\
\hline B 684 & $\begin{array}{l}\text { ilvD75, purFI, } \operatorname{argHI}, x y l-7, \text { sup-16(?) (unmapped } \\
\text { amber suppressor); } \mathrm{Hfr}\end{array}$ & & E. Adelberg \\
\hline
\end{tabular}

MacDonald. Biuret reagent was obtained from Hycel, Houston, Tex., U.S.A., and the human protein standard was obtained from Dade, Miami, Fla., U.S.A. Neomycin sulphate was obtained from Sigma.

Selection of haem-deficient mutants. Haem-deficient mutants were isolated by selection with neomycin as described previously (Săsărman et al., 1970).

Extraction and identification of porphyrins from bacterial cultures. Bacteria.were grown for $3 \mathrm{~d}^{\top}$ at $37^{\circ} \mathrm{C}$ in Roux bottles and harvested by washing the agar with saline. The cells were collected by centrifugation. The bacterial pellet and the supernatant were extracted separately. Porphyrins were extracted by the ethercyclohexanone method as adapted for bacteria (Săsărman et al., 1975). The yield of porphyrins was calculated using the molar absorption coefficients for free porphyrins with the corrections recommended by Rimington (1960) and Porra \& Falk (1964) and was expressed in nmol (g dry wt bacteria) ${ }^{-1}$.

Identification of isomers of URO and COPRO. Free porphyrins were esterified by the methanol-sulphuric acid method (Falk, 1964). Isomers of URO were identified by the method of Falk \& Benson (1953) and of COPRO by the method of Chu et al. (1951), using Chromagram cellulose thin-layer plates (Eastman Organic Chemicals Division) as described by Gajdos \& Gajdos-Török (1969) and Gajos-Török (1968).

Synthesis of pyrroles in cell-free extracts of bacteria. Bacteria were grown aerobically at $37^{\circ} \mathrm{C}$ to latestationary phase $(18 \mathrm{~h})$ in BHI. After separation by centrifuging, the cells were disrupted in an ultrasonic cell disintegrator (model Biosonik III, Bronwill Scientific, Rochester, N.Y., U.S.A.). The preparation was then centrifuged for $40 \mathrm{~min}$ at $14000 \mathrm{~g}$ at $4{ }^{\circ} \mathrm{C}$. Extracts were used immediately or stored at $-20^{\circ} \mathrm{C}$. The protein content of the extracts was determined by the biuret method (Layne, 1957); it varied from 20 to $30 \mathrm{mg} \mathrm{ml}^{-1}$.

Pyrrole synthesis in cell-free extracts of bacteria was assayed by two methods. In the first, the assay 
Table 2. Porphyrin synthesis in cell extracts

Extracts were assayed in mixtures containing $0.5 \mu \mathrm{mol} \mathrm{PBG}$ and $3.3 \mathrm{~mm}-\mathrm{EDTA}$ in $0.1 \mathrm{M}-\mathrm{Tris} / \mathrm{HCl}$ buffer, $\mathrm{pH} 8 \cdot 2$, as described in Methods.

$\begin{array}{llcccc}\text { Strain } & \text { Incubation conditions } & \text { URO } & \text { COPRO } & \text { PROTO } & \text { Total } \\ \text { SASz31 } & \text { Aerobic }(4 \mathrm{~h}) & 43^{*} & 0 & 0 & 43 \\ & \text { Anaerobic }(16 \mathrm{~h})+\text { aerobic }(2 \mathrm{~h}) & 86 & \text { trace } & 0 & 86 \\ \text { SAS245 } & \text { Aerobic }(4 \mathrm{~h}) & 31 \dagger & 2 & 4 & 37 \\ & \text { Anaerobic }(16 \mathrm{~h})+\text { aerobic }(2 \mathrm{~h}) & 0 & 39 & 47 & 86\end{array}$

* URO I. † URO I+URO III.

mixture, containing $1 \mathrm{ml}$ extract, $0.5 \mu \mathrm{mol}$ PBG and $3.3 \mathrm{~mm}$-EDTA in $0.1 \mathrm{M}$-Tris/HCl buffer, $\mathrm{pH} 8 \cdot 2$ (Bogorad, 1962), was incubated aerobically at $29^{\circ} \mathrm{C}$ for $4 \mathrm{~h}$. In the second, $2 \mathrm{ml}$ extract were added to the same ingredients and incubated for $16 \mathrm{~h}$ in anaerobiosis; then a further $1 \mathrm{ml}$ extract was added to the mixture and incubation was continued for another $2 \mathrm{~h}$ in aerobiosis at $29{ }^{\circ} \mathrm{C}$ ('anaerobic-aerobic' method). Porphyrins synthesized in the various mixtures were extracted by the ether-cyclohexanone method (Săsărman et al., 1975).

Assay of catalase activity. Catalase activity was assayed by the method of Herbert \& Pinsent (1948).

Mapping of the hemD locus. Mapping of the hemD locus was performed by phage P1-mediated transduction (Lennox, 1955). To increase the frequency of transduction, which is very low with haem-deficient recipients, the phage lysates were irradiated by an optimal dose of ultraviolet light (Wilson, 1960).

\section{RESULTS}

\section{Biochemical study of the mutant}

Strain SASZ31 originates from $E$. coli $\mathrm{K} 12$ SAS245 (Table 1) and was obtained by selection with neomycin as described previously (Săsărman et al., 1970). As expected for a haemdeficient mutant, it formed dwarf colonies on BHI agar (Difco). Prolonged incubation of the mutant on BHI agar led to the accumulation of large amounts of URO [162 nmol $\left(\mathrm{g} \mathrm{dry} \mathrm{wt}^{-1}\right.$ ] and COPRO [646 $\mathrm{nmol}\left(\mathrm{g} \mathrm{dry} \mathrm{wt}^{-1}{ }^{-1}\right.$. The isomer of COPRO, as determined by the method of Chu et al. (1951), was isomer I, which one would expect to be accumulated in UROGEN III cosynthase deficiency (Fig. 1).

To confirm the supposed deficiency of the mutant, porphyrin synthesis by cell extracts was examined in aerobic and anaerobic ('anaerobic-aerobic' method) conditions (see Methods). In both conditions, the mutant synthesized only URO (URO I) although the yield was better with the second method (Table 2). The absence of COPRO is paradoxical since synthesis in vivo gives predominantly COPRO I. Similar results were obtained earlier with an UROGEN III cosynthase-deficient mutant of Salmonella typhimurium (Săsărman \& Desrochers, 1976). After $4 \mathrm{~h}$ aerobic incubation (first method) extracts of the original strain, SAS245, synthesized mainly URO; the analysis of the isomers showed a mixture of URO I and URO III (Table 2). When the incubation was prolonged and synthesis took place mainly in anaerobiosis ('anaerobic-aerobic' method), only COPRO and protoporphyrin (PROTO) were found (Table 2). These results demonstrate the efficiency of the second method since both porphyrins derive from UROGEN III.

The catalase activity of the mutant was negligible when tested in $18 \mathrm{~h}$ cultures, but clearly positive in $48 \mathrm{~h}$ cultures (Fig. 2). However, even in $48 \mathrm{~h}$ cultures, the catalase activity of the mutant did not reach the level of the activity of the original strain. The 'delayed' synthesis of catalase by the mutant would suggest that haem synthesis by a deficient enzyme continues during the stationary phase. In contrast, the catalase activity of the original strain was not influenced by the age of the culture in the limits of 18 to $48 \mathrm{~h}$. 


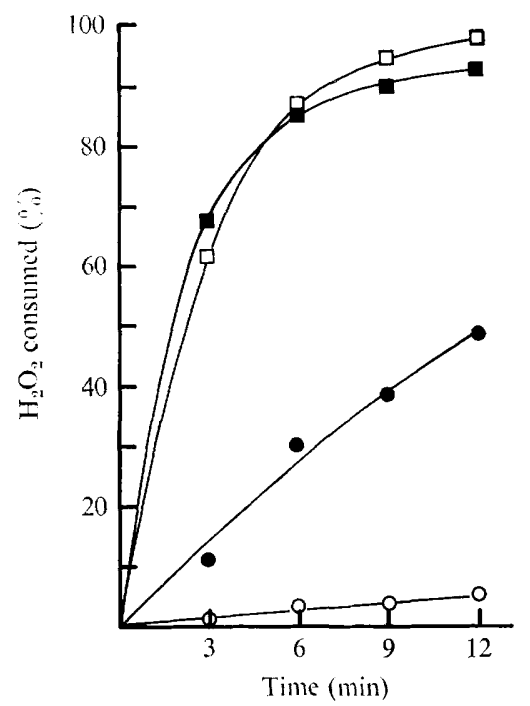

Fig. 2. Catalase activity in cultures of different ages of $E$. coli $\mathrm{K} 12 \mathrm{SASz} 31(18 \mathrm{~h}, O ; 48 \mathrm{~h}, \bullet)$ and E. coli $\mathrm{K} 12 \mathrm{SAS} 245(18 \mathrm{~h}, \square ; 48 \mathrm{~h}, \mathbf{\square})$.

Table 3. Phage P1-mediated transduction experiments

\begin{tabular}{|c|c|c|c|c|c|c|}
\hline \multirow[b]{2}{*}{ Donor } & \multirow[b]{2}{*}{ Recipient } & \multirow{2}{*}{$\begin{array}{c}\text { Selected } \\
\text { marker }\end{array}$} & \multirow{2}{*}{$\begin{array}{l}\text { No. of } \\
\text { trans- } \\
\text { ductants } \\
\text { analysed }\end{array}$} & \multicolumn{3}{|c|}{ Donor alleles in transductants $(\%)$} \\
\hline & & & & $\overrightarrow{i l v D}$ & $c y a$ & met $E$ \\
\hline SAS343 & SASZ31 & hem $D^{+}$ & 483 & $54 \cdot 2$ & $54 \cdot 2$ & $8 \cdot 1$ \\
\hline AB 684 & SASZ31 & hemD $D^{+}$ & 196 & $54 \cdot 1$ & & $10 \cdot 2$ \\
\hline Hfr Cavalli & SASZ31 & hemD $D^{+}$ & 100 & & & 12 \\
\hline PA6021 & SAS343 & ilv $D^{+}$ & 196 & 100 & $26 \cdot 9$ & \\
\hline LS853 & SAS 229 & ilv $D^{+}$ & 104 & 100 & $13 \cdot 5$ & $4 \cdot 8$ \\
\hline LS853 & SAS229 & $m e t E^{+}$ & 104 & $7 \cdot 7$ & $26 \cdot 9$ & 100 \\
\hline
\end{tabular}

Table 4. Analysis of classes of transductants*

\begin{tabular}{|c|c|c|c|c|}
\hline \multirow[b]{2}{*}{ Class of transductants } & \multirow{2}{*}{$\begin{array}{l}\text { No. of } \\
\text { transductants }\end{array}$} & \multicolumn{3}{|c|}{ No. of crossovers if the sequence is: } \\
\hline & & hemD-ilvD-cya & ilvD-hem & ilvD-cya-hemL \\
\hline $\begin{array}{l}\text { ilv } D^{+} \text {hem } D^{+} \text {cya } \\
\text { ilv } D^{+} \text {hem } D^{+} \text {cya } \\
\text { ilvD hem } D^{+} \text {cya } \\
\text { ilvD hem } D^{+} \text {cya } a^{+}\end{array}$ & $\begin{array}{l}108 \\
113 \\
148 \\
114\end{array}$ & $\begin{array}{l}2 \\
4 \\
2 \\
2\end{array}$ & $\begin{array}{l}2 \\
2 \\
2 \\
2\end{array}$ & $\begin{array}{l}2 \\
2 \\
2 \\
4\end{array}$ \\
\hline Total & 483 & & & \\
\hline
\end{tabular}

Mapping the hemD gene

The results of Pl-mediated transduction experiments are presented in Table 3 . The data obtained in the cross $\mathrm{P} 1 / \mathrm{SAS} 343 \times \mathrm{SASZ} 31$ suggest that hemD is located between $i l v$ and $c y a$, as the frequencies of associated transduction with both genes were the same $(54 \cdot 2 \%)$. The high frequency of cotransduction of hemD with ilv was confirmed in an independent cross (PI/AB684 $\times$ SASz31, Table 3). The results of reference crosses (Table 3) were generally in agreement with the results expected for the corresponding markers, according to the linkage map of $E$. coli $\mathrm{K} 12$ (Bachmann et al., 1976). However, they indicate that cya might be closer to met $E$ than shown on the published map. 
The results of the analysis of classes of transductants (Table 4) confirm the sequence ilv-hemD-cya, suggested by the analysis based on linkage frequencies. Hence, both data suggest that hemD is located in E. coli $\mathrm{K} 12$ between ilv and cya at about min 83 of the chromosomal map.

\section{DISCUSSION}

The accumulation of URO and COPRO I by the mutant clearly indicates a deficiency in the conversion of PBG to UROGEN III. This defect may be due to a mutation in the hemD gene which codes for UROGEN III cosynthase. A mutation in the hemC gene coding for UROGEN I synthase is less probable (Săsărman \& Desrochers, 1976) since mixed extracts of the hemD mutant and of a hemC mutant were able to form PROTO from PBG; the same extracts separately could not synthesize PROTO when incubated with PBG (results not shown).

The identification of the first UROGEN III cosynthase-deficient mutant in E. coli $\mathrm{K} 12$ provides the opportunity of studying the highly controversial step of UROGEN III synthesis (Lascelles, 1964; Tait, 1968; Frydman et al., 1975; Higuchi \& Bogorad, 1975; Shemin, 1975 ) with a bacterial model. In such a study, a great number of hemD and hemC mutants as well as their reciprocal complementation should be investigated. The improved method of assay of porphyrin synthesis by cell extracts described in the present report could facilitate a large-scale investigation.

The mapping of the hemD gene suggests that it is located between ilv and cya. This location is far from that of other hem genes of $E$. coli $\mathrm{k} 12$ with the exception of the popE gene mapped by Powell et al. (1973). The popE gene corresponds to the hemC gene in our nomenclature. The hemD and hemC genes are also closely located in $S$. typhimurium (Săsărman \& Desrochers, 1976). However, in S. typhimurium both genes are located on the same side of the cya gene, whereas in $E$. coli they are separated by cya. Since the location of the popE gene is provisional (Bachmann et al., 1976; Powell et al., 1973), it is not impossible that the popE gene is located between ilv and cya rather than between cya and metE as indicated on the published map.

We are indebted to Michèle Paris for her precious contribution to this work. This investigation was supported by grant MA4997 from the Medical Research Council of Canada to A.S. During this investigation, P.C. was the recipient of a studentship from the Medical Research Council of Canada.

\section{REFERENCES}

BachmanN, B. J., Low, K. B. \& Taylor, A. (1976). Recalibrated linkage map of Escherichia coli K12. Bacteriological Reviews 40, 116-167.

Bogorad, L. (1958). The enzymatic synthesis of porphyrins from porphobilinogen. II. Uroporphyrin III. Journal of Biological Chemistry 233, $510-515$.

Bogorad, L. (1962). Porphyrin synthesis. Methods in Enzymology 5, 885-895.

Chu, T. C., Green, A. A. \& Chu, E. J. (1951). Paper chromatography of methyl esters of porphyrins. Journal of Biological Chemistry 190, 643-646.

FaLK, J. E. (1964). Porphyrins and Metallo-porphyrins. New York: American Elsevier.

FALK, J. E. \& BenSON, A. (1953). Separation of uroporphyrin esters I and III by paper chromatography. Biochemical Journal 55, 101-104.

Frydman, B., Frydman, R. B., Valasinas, A., LeVy, S. \& Feinstein, G. (1975). The mechanism of uroporphyrinogen biosynthesis. Annals of the New York Academy of Sciences 244, 371-395.

Gajdos, A. \& Gajdos-TöröK, M. (1969). Porphyrines et Porphyries. Paris: Masson et Cie.

Gajdos-TöröK, M. (1968). Séparation des porphyrines par chromatographie en couche mince de cellulose. Bulletin de la Société de chimie biologique 50, 925-928.

Herbert, D. \& Pinsent, J. (1948). Crystalline bacterial catalase. Biochemical Journal 43, 193-202.

Higuchi, M. \& Bogorad, L. (1975). The purifica tion and the properties of uroporphyrinogen I synthase and uroporphyrinogen III cosynthase. Interactions between the enzymes. Annals of the New York Academy of Sciences 244, 401-418.

LasCelles, J. (1964). Tetrapyrrole Biosynthesis and its Regulation. New York: W. A. Benjamin.

LAYNE, E. (1957). Spectrophotometric and turbidimetric methods for measuring proteins. In Methods in Enzymology 3, 447-454.

LENNOX, E.S. (1955). Transduction of linked genetic characters of the host by bacteriophage P1. Virology 1, 190-206. 
LEVIN, E. Y. (1975). Comparative aspects of porphyria in man and animals. Annals of the New York Academy of Sciences 244, 481-495.

Perrin, D. D., Armarego, W. L. F. \& Perrin, D. P. (1966). Purification of Laboratory Chemicals. Oxford: Pergamon Press.

Porra, R. J. \& Falk, J. E. (1964). The enzymic conversion of coproporphyrinogen III into protoporphyrin IX. Biochemical Journal 90, 69-75.

Powell, K. A., Cox, R., McConville, M. \& Charles, H. P. (1973). Mutations affecting porphyrin biosynthesis in Escherichia coli. Enzyme 16, 65-73.

Rimington, C. (1960). Spectral-absorption coefficients of some porphyrins in the Soret-band region. Biochemical Journal 75, 620-623.

SăsĂrman, A. \& Desrochers, M. (1976). Uroporphyrinogen III cosynthase-deficient mutant of Salmonella typhimurium LT2. Journal of Bacteriology 128, 717-721.
Săsărman, A., Sanderson, K. E., Surdeanu, M. \& SONEA, S. (1970). Hemin-deficient mutants of Salmonella typhimurium. Journal of Bacteriology 102, 531-536.

Săsărman, A., Chartrand, P., Proschek, R., Desrochers, M., Tardif, D. \& Lapointe, C. (1975). Uroporphyrin-accumulating mutant of E. coli. Journal of Bacteriology 124, 1205-1212.

SHEMIN, D. (1975). Porphyrin synthesis: some particular approaches. Annals of the New York Academy of Sciences 244, 348-355.

TAIT, G. H. (1968). General aspects of haem synthesis. In Porphyrins and Related Compounds. Edited by T. W. Goodwin. New York: Academic Press.

WILSON, D. E. (1960). The effects of ultraviolet light and ionizing radiation on the transduction of E. coli by phage $\mathrm{P} 1$. Virology 11, 533-546. 